\title{
The Notion of Unhomeliness in the Pickup: Homi Bhabha Revisited
}

\author{
Ali Akbar Moghaddasi Rostami (Corresponding author) \\ Department of Foreign Languages, Islamic Azad University, Central Tehran Branch, Iran \\ E-mail: moghaddasirostamiali@yahoo.com \\ Farid Parvaneh \\ Department of Humanities, Islamic Azad University, Qom Branch, Iran.
}

Doi:10.7575/aiac.alls.v.7n.1p.157

URL: http://dx.doi.org/10.7575/aiac.alls.v.7n.1p.157
Received: 19/09/2015

Accepted: 19/11/2015

\begin{abstract}
This study centers on two characters in Nadine Gordimer's novel The Pickup: Abdu and Julie. Abdu is an illegal immigrant in South Africa and is deported from there to his homeland. Julie who is white woman from a high social class in South Africa meets and falls in love with Abdu and moves to Abdu's unknown Islamic country. She finds her lost identity in Abdu's homeland and stays in his country and tries to adapt herself to Islamic laws and traditions, while Abdu feels unhomely in his own homeland and tries to move to the United State. The research sought to analyze these two wandering characters through the notions of unhomeliness, and in-between space. Identity of the two characters was not determined by the country.
\end{abstract}

Keywords: Post-colonial literature, Bhabha, Unhomeliness, Gordimer, Identity

\section{Introduction}

The city Johannesburg as the setting in the novel The Pickup could represent any global city separated from its surroundings and attached to the other global cities by the world market and electronic communication. This process can cause identity crisis .In fact, in this situation there is no place to fix the sense of self. In the Westernized world and in time of globalization man is facing the problem of homeliness.

According to Bhabha 'home' is perceived to be a place of stable identity where one has been and is understood. In nation and cultures that are experiencing oppression, home is linked to positive version of the past .It means a life before oppression .In other words, 'home' is tied to freedom. Bhabha develops the notion of unhomely by referring to some work of post colonial literature that problamatize the idea of the real and stable 'home'. Bhabha emphasizes on instability of 'home' and of the 'past'.

The word 'unhomely' is the translation of 'unheimlich' which is the opposite of 'heimlich'. Bhabha argues that the place between the 'heimlich' (homely) and 'unheimlich' (unhomely) is a post colonial place, a space in which one can see how a person's identity is a mixture of what is unfamiliar or foreign and what is familiar. This idea echoes the work of Sigmund Freud. To Freud as the subconscious creeps and moves into the conscious, it creates an uncanny moment. It is the same when the world creeps into the home and shakes an identity that was thought to be stable and secure.

This shock of recognition is commonly considered to be negative. Alienation is a very painful experience which one thinks to be familiar, but it is not. Bhabha suggests that the alienation which a person experiences in the 'unhomely' moment, may also present an opportunity to reevaluate one's identity. Bhabha talks about his own origins and does not claim a stable and fixed identity. He suggests that Parsis have transformational experiences, and hybrid identity. We should know that homelessness is real as well as metaphorical.

I have lived that moment of scattering of the people that in other times

And other places, in the nations of others, becomes a time of gathering.

Gathering of exiles and émigrés and refugees; gathering on the edge of

Foreign cultures; gathering at the frontiers; gatherings in the ghettoes or

Or Cafes city centers; gathering in the half-life, half-light of foreign tongues

Or in the uncanny fluency of another's language,(LC :139)

Bhabha suggests the uncanny concept as the unhomely, too. He evokes the uncanniness of migrant experience through a series of familiar ideas like- half-life, (the partial presence of colonial identity), repeats the life lived in the country of origin. However, the repetition is not identical. It introduces transformation and difference. He also says further that 
this repetition is a way of reviving that past life and keeping it alive in the present. All the uncertainties, hesitations and ambivalences which colonial authority and its figures are imbued with, are characterized in terms of the uncanny. In other word, the split in political subject can be described as uncanny. Sigmund Freud and Julia Kristeva use the idea of the uncanny. This influenced Bhabha and his sense of the hybrid, post-colonial perspective.

According to Bhabha culture has dual identity. On the one hand, it is homely or realistic, asserting its stability and coherence; on the other hand, it is unhomely because it is always changing; it is always made meaningful by others. Culture, to Bhabha, is never coherent and self -sufficient .Though its narratives seem confidence and stable, they are always drawn into displaced relationship. They are in relationship with other cultures, texts, or disciplines. He says migrants can be a good example of this dual nature of culture; they are always situated in relation to both an original culture and a new place and location. Bhabha argues that the uncanny possibly has more power when it is applied to the homeliness of the colonizer, when it is used to explore the foreignness that is central to original and self-sufficient source of colonization. Bhabha points out that the relationship between self and other is always an uncanny one. He says uncanniness is not only a question of place, but also of time, since our sense of national identity is open and static. We don't 'own' our nation, as it is something that is our own and at the same time it is not ours, because its identity is always changing or coming from future. He adds, like culture, Western knowledge is homely and unhomely or canny and uncanny. Bhabha believes in Western and non-Western identities. Because the concept of 'uncanny' undermines the stability of all concepts in general, it seems to be a slippery concept. Bhabha is supposed to be an expert in transforming concepts as his theoretical strategies. The slippery means it tends to elude definite theorization. By using canny and uncanny, Bhabha focuses the colonial relationship -as the simple division of self and other.

\section{Abdu and Julie looking for home}

Gordimer demonstrates that belonging and sense of self are not determined by the nation's borders .Her protagonists locate their sense of self through spiritual, regional, and sexual spaces. Abdu doesn't feel homely in his country .The most important point is that throughout the story he doesn't mention his homeland. He named a country she had barely heard of. He is a migrant who lives in South Africa, a foreign territory, and faces in-between and hybrid space. Abdu is under the influences of two cultures, two different worlds: the modern world of West and the world of colonized. He tries to adapt himself with the Western and colonizer, and looking for a home in Western countries specially the U.S .Now he is suffering from dangling and no-belonging position. Even the owner of the garage for whom he is working doesn't have any respect for him. The employer suggests that Julie not get this homeless guy her friend and partner. For your own good, you are a nice girl, a somebody, I can see .He is not for you .He is not really allowed to be in the country.

Abdu and Julie both feel unhomely; one from inside her home and the other while is outside his homeland. Julie has been picked up by Abdu who symbolizes her lost sense of self. Each of the two protagonists reflects and mirrors the other's lost sense of self. Their love affairs have been formed in in-between situation.

He is here, he is not here. It's within this condition of existence that they exist as lovers'.

It is a state of suspension from the pressures of necessity to plan the way others have to plan

..... There is no future without an identity to claim it.(Gordimer 37)

Abdu the male character of the story is not only homeless in metaphorical sense but he is a real homeless from the very beginning of the story. We know nothing of his country of origin, his real name; is it Ibrahim, Abdu or Abdurrahman? $\mathrm{He}$ is also referred to as 'garage man' and á grease monkey'. He is also an economist. Where did he get his degree? The university is one that nobody's heard of. "--An economist having to become a grease monkey I wonder how he learned about cars."(Gordimer 15) Julie doesn't really understand where he said he was from .In response to the question about his country of origin he says:

I can't say that -'my country'-because somebody else made a line and said that is it. In my

Father's time they gave it to the rich who run it for themselves. So whose country I should

Say, it's mine. (Gordimer 15)

Because he is a black, from outside, he is exploited by the owner of the garage he is working. The garage employed him illegally -'black' that is the word they use. It is cheap for the owner. The owner doesn't pay accident insurance, pension, and medical aid. So Abdu is treated as a real homeless in Julie's country.

\section{Social and Economical Status of Abdu and Julie}

Abdu is from a third world country. The community that he grew up is Islamic. It is a primitive society with microbourgeois class. The Islamic culture is dominant. Abdu's family doesn't like and approve western and European culture. They think western culture is corrupted. The social class that Abdu belongs to is so inferior to Julie's. Therefore, he isn't willing to talk about his family status, his country and the things. Julie is living in South Africa; from a well-to do family with European culture which is the opposite of Abdu's society. Julie doesn't feel cheerful in her industrialized homeland. Her father is an investment banker. She doesn't like her father's idea. When her father learns she has made love with Abdu, an immigrant from unknown land, he cuts her allowance. When Julie goes to her father and informs him of her marriage and her leaving the country, he gets annoyed and talks about social class distinction: 
Make something of your life and all the advantages you've had-including your freedom

You're nearly thirty. And now you come here without any warning and simply tell us you

Are leaving in a week's time for one of the worst, poorest and most backward of Third

World countries, following a man who's been living here illegally, getting yourself deported

Yes- from your own country... You are out of your mind. What more can I say. You choose

To go hell in your own way (Gordimer 98)

To Julie, going to Arab country is going to paradise. Here in her ancestor's country she feels lonely and homeless .She is living at home abroad or abroad at home.(Bhabha) There is a big gap between the two social, cultural and economical statuses .Julie is not free to live in South Africa, what her father says; she feels free in Abdu's desert land. She sees her true identity in Abdu. Julie desires to go to Abdu's country, but her family refuses to help him to get legal document to stay there. Julie hates South Africa, the country of exploitation, discrimination, poverty, and cruelty .She would like to marry Abdu and immigrate to her Islamic country as early as possible, so she purchases two tickets which make Abdu so angry. He thinks that Julie can not live with his family and it is impossible for her to adapt their culture.

\section{Julia's Desired Land}

Though Abdu does not approve of his culture and socio economic system of his country, he tries to follow the traditions and cultural codes as long as he is there. So he wants Julie to go to Magistrate's Court to marry her formally .He can not take a woman to his family without a formal marriage. Julie feels a strong affinity with Abdu's family, but she needs to learn the language .She at least knew enough to observe the etiquette that here it was impolite to refuse anything offered.(Gordimer120). She has sense of home here in Abdu's country and feel comfortable. She is eager to learn more about his family, relatives, and their traditions. Abdu's family helps her to comply herself as much as possible with their regulation, rules, and traditions. They want her to cover her head when she is out.

Abdu doesn't feel comfortable in his home land. He is shocked that Julie expresses her interests and willing to stay here in a backward country. For example every morning, afternoon and evening they hear muezzin is calling for prayer in the mosque and this is bothering for Abdu and wouldn't like to hear it .He explains to Julie that "that is what we have in the miracle of technology in our place." (G. 125) Abdu makes fun of his people's beliefs, ideas, traditions and even their religious ceremony. He thought Julie who is from a developed country and of higher social class would be a great help to locate his home to settle; unfortunately, she is longing to adapt herself and live here. Julie finds her real home and her lost identity when she meets Abdu. Abdu's sister, Maryam, is helping Julie to pick up the language and customs of the new homeland. Maryam has become fluent in speaking and understanding English. Julie is mingling in new unknown Islamic nation more and more but Abdu is out of this exchange. Abdu is a foreign in his own homeland and finally decided to leave the country without his wife and go to the United State. Therefore their marriage was not based on love. They have nothing to share .Julie accepts the ceremony of the month of Ramadan and performs the ritual of this month.

\section{Abdu's Dream Land}

Abdu is not free in his own homeland .He is considered as political troublemaker in his land. He made a big mistake to return to his country. Because he escaped from his country to South Africa, he shouldn't have returned to his country. He thought through his marriage to Julie he could solve the problem and would be able to go to any country that they would like. Unfortunately, Julie found her desired and dreams home. He tried to get of his country but "as he has been refused a passport at this end of the process because there is a record of a political troublemaker as a student against the regime, he hasn't the first requirement of the many for the visa application."(GordimerP.176)

Therefore Abdu has become captive in his country and trying to escape again and find his true homeland to settle. His uncle, Uncle Yaqub, is a religious man. He has a workshop, and business is great for him; Abdu was said to do repair job and also go on business of buying and selling of American and German second hand automobiles. Uncle Yaqub is against his nephew. He doesn't want Ibrahim to go and spend time with malcontents who blame the government and authorities. About political malcontents, Uncle Yaqub says:

The Lord has given them what a man needs to live a good life in the Faith, their family have

Educated them, they can marry and bring up children in security, there are no foreigners

From Europe flying flags over our land any longer-what more do they want.. They want to

Bring down government. That's the evil they want.(Gordimer P.189)

However, Abdu doesn't want to live there and doesn't show any interest to work in his uncle's workshop. He is considered as a foreigner in his own homeland. In Uncle Yaqub's point of view, Abdu and his friends who are educated and think of modernity are foreigners ; they are dangerous , a danger to government and people of their country.

\section{Conclusion}

Gordimer in her recent novel The Pick up metaphorically expresses that colonialism has created a problem in the world. It can not be said the colonialism has completely disappeared from the society. One of the most serious problem of this 
age, the post-colonialism period is, unhomeliness. Characters in her novel are wandered and homeless, looking for their true identity to pick up. In the metropolitan area of South Africa this is a big problem. In the process of colonization and social, political oppression many people left their homeland or even on their own home land are feeling unhomely. Gordimer portrays the problem of a white character who represents the colonizer's and one black character from third world country representing the colonized.

\section{References}

Ashcroft, \& Griffiths, G. (1989) The Empire writes back: Theory and practice in post-colonial literatures. London: Routledge.

Ashcroft, B., \& Griffiths, G (2000), Post-colonial studies the key concepts. London: Routledge

Bhabha, H. (1994) the location of culture London: Routledge.

Bhabha, H. (1990) Nation and Narration London: Routledge

Cohn, B. (1996). Colonialism and its forms of knowledge: the British in India. Princeton, N.J.: Princeton University Press.

Gordimer, N. (2001). The Pickup New York: Farrar, Straus, and Giroux.

Huddart, D. (2005). Homi K. Bhabha. London: Routledge.Lionnet, F. (1995). Postcolonial representations: Women, literature, identity. Ithaca, New York: Cornell University Press.

Lodge, (N.D.). 20th century literary criticism: A reader / edited by David Lodge.

Loomba, A. (1998). Colonialism- post colonialism London: Routledge.

Thurston, B. (1999). Nadine Gordimer revisited. New York: Twayne. 